\title{
JAUNINAMASIS KOSMETINĖS KAUKĖS POVEIKIS SENSTANČIAI ODAI
}

\author{
Birutė Kaušilaitė ${ }^{1}$, Auksė Juškevičiene் ${ }^{2}$, Vaiva Vaikšnoriené2 $\dot{2}^{2}$ Žaneta Mickienė², \\ Loreta Valatkevičiené2 $\dot{e}^{2}$ Audronė Klimavičiene் ${ }^{2}$, Sandrija Čapkauskiené2,3 \\ ${ }^{1} U A B$,,Pharmadia“, ${ }^{2}$ Kauno kolegija, Kosmetologijos katedra, \\ ${ }^{3}$ Lietuvos sporto universiteto Taikomosios reabilitacijos ir biologijos katedra
}

Raktažodžiai: kosmetinė kaukè, senėjimas, drègmè, elastingumas, raukšlès.
Santrauka
Senstant gilëja jau susiformavusios veido raukšlès, veido ovalas slenka žemyn, įdumba skruostai, lei- džiasi antakių sritis, gilèja akiduobès, sutrikdoma normali veido odos kraujotaka. Keičiasi hormonu pusiausvyra, o postmenopauziniu periodu sumažèjusi estrogenų koncentracija sąlygoja kolageno degrada- ciją, vandens netekimą, elastingumo praradimą. Dèl didelio užimtumo ir nevienodų finansinių galimybių dalies moterų kasdienè veido priežiūra apsiriboja tik odos valymu bei kremo naudojimu. Siekiant geresnio rezultato yra reikalingos papildomos kosmetinès prie- monès: šveitikliai, kaukès, serumai. Tyrimo metodai: 1) odos būklès įvertinimas diagnostiniu aparatu ,,Skin analyzer Soft plius " 2) jauninamosios kaukès proce- dūros: atlikta 16 procedūrų, 2 kartus/savaitę. Tyrime dalyvavo dvidešimt keturios 35-50 metų amžiaus moterys. Rezultatai: drègmè kaktos srityje padidejo nuo $58,9 \pm 10,2$ (sąlyginiai v.) iki $65,5 \pm 10$ (sąlyginiai v.) pasibaigus tyrimui $(\mathrm{p}<0,05)$, skruostuose drègmès padidejjimas užfiksuotas nuo $62,5 \pm 10$ (sąlyginiai v.) tyrimo pradžioje iki $69 \pm 10,5$ (sąlyginiai v.) tyrimo pa- baigoje $(\mathrm{p}<0,05)$. Elastingumas taip pat padidejo nuo $40 \pm 3,3$ (sąlyginiai v.) tyrimo pradžioje iki 47,5 $\pm 3,9$ (sąlyginiai v.) pabaigoje ir net praejus 2 savaitems po tyrimo išliko padidèjęs - 45 $\pm 2,9$ (sąlyginiai v.) $(p<0,05)$. Raukšlių gylis patikimai sumažejo ir išliko mažesnis po 2 savaičių lyginant su pradine jų verte $(p<0,05)$. Jutiminiai ir vizualiniai veido odos rodikliai pagerèjo $(\mathrm{p}<0,05)$. Išvados: veido odos drègmè kaktos bei skruostų srityse ir odos elastingumas reikšmingai padidejo po 8 savaites taikytų jauninamujjų kaukès procedūrų. Šio tipo kauke taip pat turejo teigiamą,

reikšmingą poveikị trijų raukšlių, matuotų ties išoriniu akiduobès kampu, gyliui. Jauninamoji kaukè padare teigiamą ịtaką ir subjektyviems veido odos rodikliams. Vizualiniai - skaistumas ir šerpetojimas bei jutiminiai - tempimas, švelnumas ir stangrumas - rodikliai reikšmingai pagerèjo.

\section{İvadas}

Senejjimas tai kompleksinis biologinis procesas. Lètèjant gyvybinèms organizmo funkcijoms, prasideda individualūs išvaizdos pokyčiai: drègmès trūkumas, elastingumo mažejimas, raukšlių formavimasis, spalvos pakitimai ir kt. [1]. Veiksniai, kurie susiję su senèjimu, yra nemodifikuoti: genetika, lytis, amžius, tačiau didelę įtaką senejjimui turi ir modifikuojantys veiksniai - rūkymas, mityba, mažas aktyvumas, stresas, UV (ultravioletiniai) spinduliai [2].

Senstant sutrinka epidermio ir dermos funkcijos. Sumažejjus dermos pamatinio sluoksnio ląstelių dalijimosi greičiui epidermis nebesugeba greitai atsinaujinti, todèl mažeja gyvybingų ir daugeja mirusių ląstelių skaičius. Šie pokyčiai pakeičia keratinocitų funkcinį aktyvumą, ìvairių augimo faktorių sintezę, kas pablogina odos būklę [3]. Senstančios odos paviršiuje keratinocitai linkę kartu sulipti - taip suteikdami odai šiurkštumą, žvynuotą išvaizdą ir tekstūrą [4]. Sulètejus odos regeneracijos procesui, pasikeičia epidermio vientisumas - jis ženkliai suplonèja, o raginis sluoksnis sustorejja. Suplonejus epidermiui, padideja veido odos jautrumas išoriniams aplinkos veiksniams, gali išryškèti smulkiosios kraujagyslès. Sumažèjęs kolageno ir elastino skaidulų kiekis bei pasikeitusi jų struktūra sąlygoja odos tonuso pakitimus bei raukšlių formavimąsi [5]. Kolagenas sudaro apie $80 \%$ odos masès. Senstant kolageno skaidulos odoje tampa storesnès ir mažiau tamprios. Kolageno elastingumą mažina laisvieji radikalai, jo sintezę lètina ir su amžiumi atsirandantys hormoniniai pokyčiai (menopauzès metu oda netenka elastingumo ir tamprumo kelis kartus greičiau) bei neigiami 
išorès veiksniai (rūkymas, ultravioletiniai saulès spinduliai, užteršta aplinka) [4]. Kolagenas pasižymi ne tik gebẻjimu išlaikyti odos elastingumą, bet taip pat jis yra svarbus palaikant drègmès balansą. Moters organizme, vykstant hormoniniams pokyčiams, nykstant kolageno sugebėjimui sugerti ir išlaikyti vandenį, oda praranda drègmę, elastingumą, suglemba. [6]. Drègmès balanso atstatymas odoje yra vienas svarbiausių žingsnių sveikos odos priežiūroje [7]. Sveika oda turi savyje daug vandens, kuris padeda palaikyti kūno temperatūrą ir neleidžia odai išsausèti [8]. Senstant vandens kiekis epidermyje mažeja . Tam ịtakos turi ir epidermio lipidinio barjero pažeidimas, kurị sudaro laisvosios riebalų rūgštys, keramidai, cholesterinas ir jo eteriai. Dermoje, kuri yra glaudžiai susijusi su odos kolagenu, yra nedideli kiekiai ịvairių gliukozaminoglikanų (įskaitant heparino sulfatą), kurių kiekis senstant žymiai sumažeja. Manoma, kad šie glikozaminoglikanai turi dideles vandens išlaikymo galimybes ir yra būtini normaliam odos drègnumui palaikyti $[4,9]$. Didžiausią įtaką senstant odai turi kolageno degradacija ir estrogenų nepakankamumas. Su amžiumi oda tampa trapi, jautri traumoms, dažniau odoje pastebimos kraujosruvos. Postmenopauzinis estrogenu trūkumas odoje pasireiškia: atrofija, kolageno degradacija, vandens netekimu, elastingumo praradimu ir hiperandrogenizmu. Per pirmuosius 5 metus nuo menopauzès pradžios prarandama apie $30 \%$ kolageno ir vidutiniškai apie $2,1 \%$ kasmet. Jungiamojo audinio nykimas senstant turi įtakos odos tonuso praradimui, todèl palaipsniui gilèja jau susiformavusios veido raukšlès, keičiasi veido ovalas, riebalinis sluoksnis slenka žemyn, įdumba skruostai, leidžiasi antakių sritis, gilèja akiduobės, pažeidžiamos kraujagyslių sienelès, kas trukdo palaikyti normalią odos kraujotaką $[9,10]$.

Kosmetologijos kabinete teikiamos profesionalios paslaugos gali padèti sumažinti senstančios veido odos požymius,

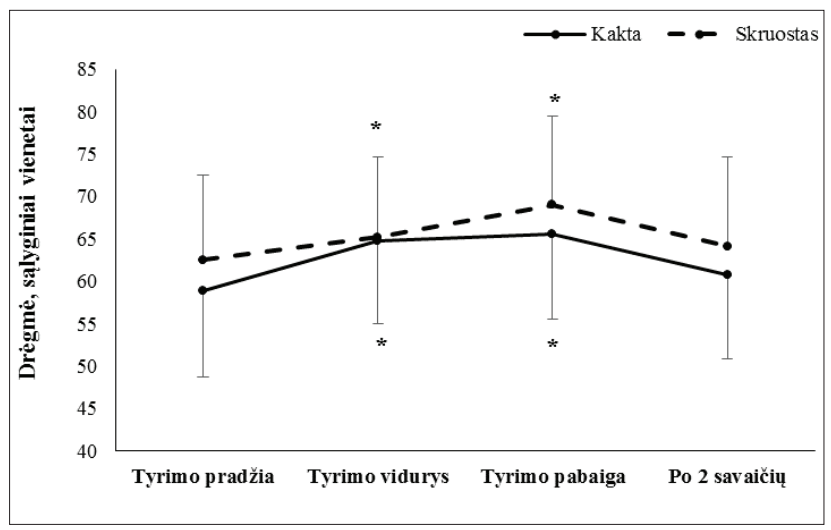

1 pav. Veido odos drėgmės pokyčiai kaktos bei skruosto srityse po taikytų antisenèjimo kaukès procedūrų

${ }_{p}<0,05$ - statistiškai reikšmingas skirtumas lyginant drègmès ịvertị tyrimo pradžioje su drègme tyrimo viduryje, pabaigoje ir praèjus 2 savaitems po tyrimo. tačiau ne mažiau svarbi ir kasdieninè priežiūra. Dèl didelio užimtumo ir nevienodų finansinių galimybių dalies moterų kasdiené priežiūra apsiriboja veido odos valymu ir kremo tepimu. Siekiant geresnio rezultato reikalingos papildomos kosmetinès priemonès: šveitikliai, kaukès, serumai. Buvo aktualu įvertinti šiuolaikinèmis technologijomis sukurtų vienkartinių kosmetinių kaukių, skirtų naudoti namuose, poveikį gerinant senstančios veido odos požymius.

Tyrimo tikslas: įvertinti šiuolaikinèmis technologijomis sukurtų vienkartinių kosmetinių kaukių, skirtų naudoti namuose, poveikį gerinant senstančios veido odos požymius.

\section{Tyrimo medžiaga ir metodai}

Tyrime dalyvavo dvidešimt keturios 35-50 metų amžiaus moterys. Tiriamujų atrankos kriterijai: amžius, 1 mèn. iki tyrimo pradžios netaikytos intervencinès grožio procedūros. Tyrimo eigoje dalyvès turèjo laikytis šiu sąlygų: taikyti iprastą kasdieninę savo veido odos priežiūrą namuose, nenaudoti papildomų veido odos būklę gerinančių veiksnių, nesilankyti soliariume, nekeisti iprastos gyvensenos. Visoms tiriamosioms buvo atlikta 16 procedūrų, naudojimo dažnumas - 2 procedūros per savaitę. Buvo ịvertinti objektyvūs odos ir subjektyvūs moteru jutiminiai bei vizualiniai rodikliai. Objektyvių odos parametrų ịvertinimas diagnostiniu aparatu ,,Skin analyzer Soft plius” buvo atliekamas prieš kiekvieną procedūrą ir praèjus 2 savaitèms po paskutinès procedūros. Buvo ịvertinti tokie veido odos būklès parametrai kaip drégmè kaktos ir skruostų srityje, elastingumas ir trijų raukšlių gylis ties akiduobės išorine puse. Subjektyvūs veido rodikliai buvo ịvertinti anketavimu po kiekvienos procedūros. Buvo vertinti jutiminiai rodikliai - veido odos tempimas, švelnumas, stangrumas (tonusas) bei vizualiniai rodikliai - odos skaistumas (spalvos vientisumas) ir šerpetojimas. Subjektyvūs veido rodikliai vertinti balais: 0 - visai

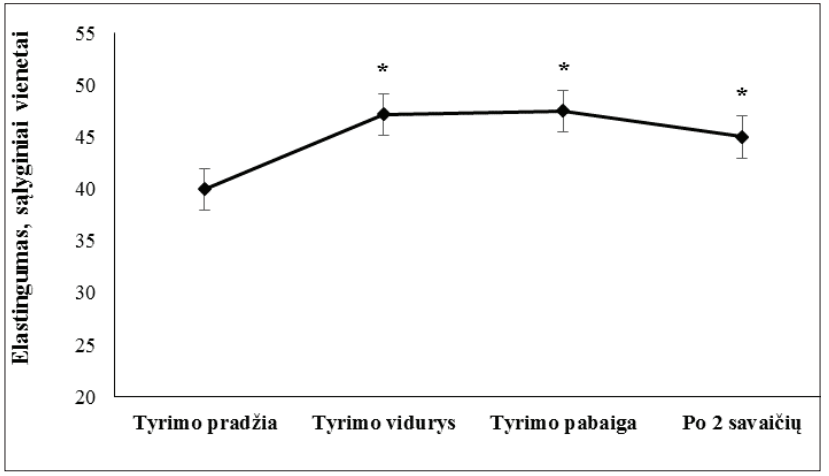

2 pav. Veido odos elastingumo pokyčiai po taikytų antisenèjimo kaukès procedūru

${ }^{*} p<0,05$ - statistiškai reikšmingas skirtumas, lyginant elastingumo ịvertị tyrimo pradžioje su elastingumo verte tyrimo viduryje, pabaigoje ir praejjus 2 savaitèms po tyrimo. 


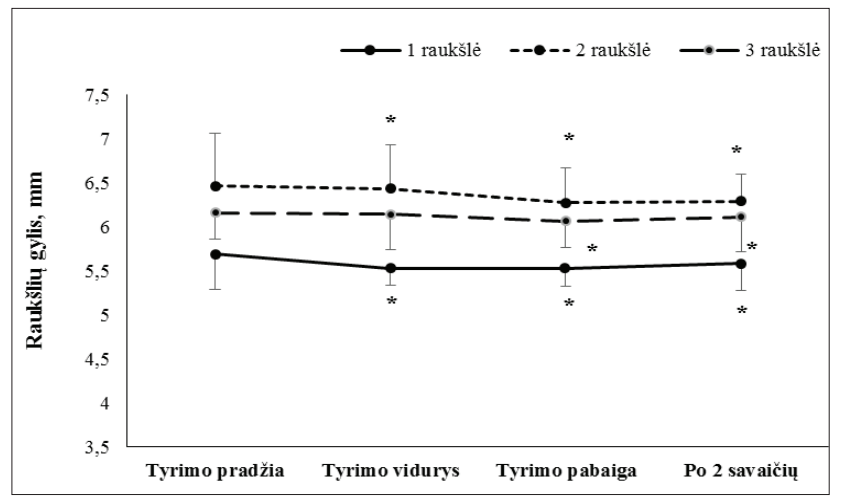

3 pav. Raukšlių gylio pokyčiai po taikytų antisenėjimo kaukès procedūrų

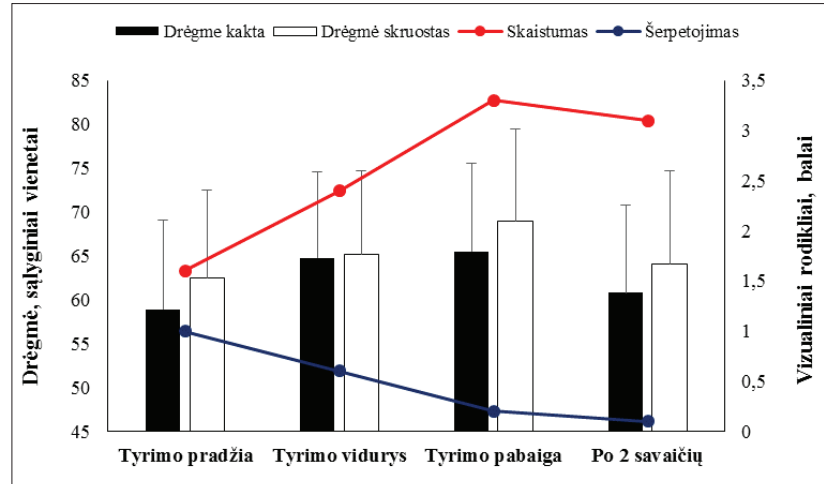

4 pav. Subjektyvių vizualinių rodiklių - skaistumo ir šerpetojimo - palyginimas su drėgmės pokyčiais kaktos ir skruostų srityse po taikytų antisenèjimo kaukès procedūrų $(\mathrm{p}<0,05)$

Subjektyvūs veido rodikliai vertinti balais: 0 - visai nèra, 1 -nežymūs pojūčiai, 2 kartais pasireiškia, 3 - ryškūs, 4 - labai ryškūs.

nèra, 1 - nežymūs pojūčiai, 2 - kartais pasireiškia, 3 - ryškūs, 4 - labai ryškūs. Taikytą jauninamają kaukę sudaro: hialurono kompleksas, alijošiaus ekstraktas, acetiltetrapeptidas 15, šilko baltymai, acetilheksapeptidas B, niacinamidas vit. B3, acetilheksapeptidas 12, tokaferolio acetatas, alfa lipoliné rūgštis, kofermentas Q 10.

Statistinè analizė atlikta taikant SPSS programos 19.0 versiją ir taikant Microsoft Office Excel 2011 programą. Buvo apskaičiuoti analizuojamų rodiklių aritmetiniai vidurkiai ir vidutinis standartinis nuokrypis. Siekiant įvertinti kaukès poveikį objektyviems ir subjektyviems veido odos rodikliams, buvo taikyti neparametriniai duomenų analizès metodai. Duomenu patikimumui vertinti naudotas Mano Vitney (Mann-Whitney) ir Vilkoksono (Wilcoxon) testas, kuris leido ịvertinti, ar pasikeite ir kaip pasikeite veido odos rodikliai, panaudojus jauninamają kosmetinę kaukę. Rodiklių skirtumai laikyti statistiškai reikšmingais, kai $p<0,05$.

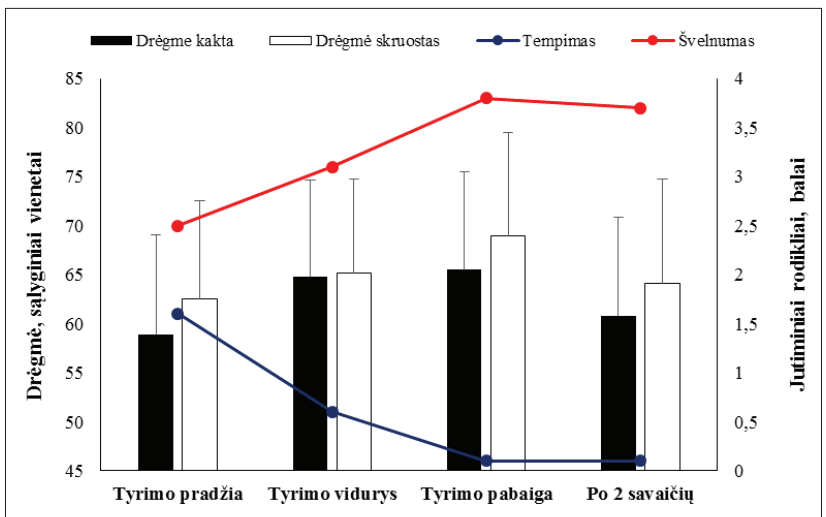

5 pav. Subjektyvių jutiminių rodiklių - tempimo ir švelnumo palyginimas su drėgmès pokyčiais kaktos ir skruostų srityse po taikytų antisenèjimo kaukès procedūrų $(\mathrm{p}<0,05)$

Subjektyvūs veido rodikliai vertinti balais: 0 - visai nèra, 1 - nežymūs pojūčíai, 2 kartais pasireiškia, 3 -ryškūs, 4-labai ryškūs

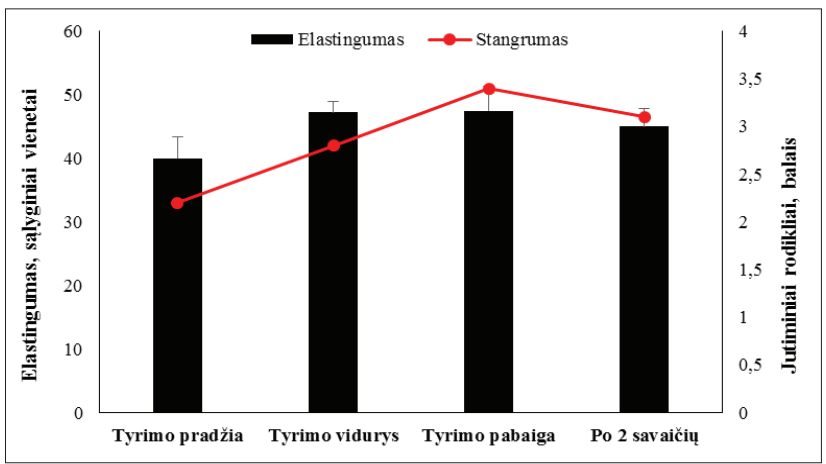

6 pav. Subjektyvaus jutiminio rodiklio - stangrumo - palyginimas su elastingumo pokyčiais po taikytų antisenèjimo kaukès procedūrų $(\mathrm{p}<0,05)$

Subjektyvūs veido rodikliai vertinti balais: 0 - visai nèra, 1 - nežymūs pojūčiai, 2 kartais pasireiškia, 3 -ryškūs, 4 - labai ryškūs

\section{Tyrimo rezultatai}

Eksperimento metu taikytos jauninamosios kaukès aplikacijos padidino veido odos drègmę kaktos ir skruostų srityse (1 pav.). Drègmès vertè kaktoje tyrimo pradžioje buvusi $58,9 \pm 10,2$ (sąlyginiai vienetai) padidejjo iki $64,8 \pm 9,8$ (sąlyginiai vienetai) $(\mathrm{p}<0,05)$ tyrimo viduryje ir iki $65,5 \pm 10$ (sąlyginiai vienetai) pasibaigus tyrimui $(\mathrm{p}<0,05)$. Po dviejų savaičių kaktos drègmès vertè reikšmingai sumažèjo iki $60,1 \pm 10$ (salyginiai vienetai) lyginant su paskutiniu matavimu pabaigus tyrimą $(p<0,05)$. Skruostų srityje reikšmingas drègmès padidejjimas buvo užfiksuotas tyrimo pabaigoje lyginant su pradine skruostų drègme tyrimo pradžioje $62,5 \pm 10$ (sąlyginiai vienetai) tyrimo pradžioje iki $69 \pm 10,5$ (sąlyginiai vienetai) tyrimo pabaigoje. Po dviejų savaičių drègmé skruostų srityje $(64,1 \pm 10,5$ sąlyginiai vienetai) reikšmingai sumažejo lyginant su paskutiniu matavimu 
pabaigus tyrimą $(69 \pm 10,5$ sąlyginiai vienetai) $(\mathrm{p}<0,05)$.

Ivertinus veido odos elastingumą ( 2 pav.), užfiksuotas reikšmingas pagerèjimas lyginant pradinę elastingumo vertę tyrimo pradžioje ( $40 \pm 3,3$ sąlyginiai vienetai), prieš pradedant taikyti antisenejjimo kaukès aplikacijas su šio rodiklio vertèmis tyrimo viduryje (47,2 $\pm 1,8$ sąlyginiai vienetai), pabaigoje $(47,5 \pm 3,9$ sąlyginiai vienetai) ir net praejjus 2 savaitems po tyrimo $(45 \pm 2,9$ sąlyginiai vienetai) $(\mathrm{p}<0,05)$. Kosmetinès kaukès sudètyje yra acetilheksapeptidas 12 , tai peptidas, kuris skatina fibroblastus aktyviau gaminti kolageną, todèl odos elastingumas gereja.

Jauninamoji kaukè turèjo teigiamą statistiškai reikšmingą poveikį trijų raukšlių, matuotų ties akiduobės išoriniu kampu, gyliui (3 pav.). Visų matuotų trijų raukšlių gylis patikimai sumažejo nuo pradinès savo vertès: 1-osios raukšlès gylis nuo $5,69 \pm 0,4 \mathrm{~mm}$ sumažejo iki $5,52 \pm 0,2 \mathrm{~mm}$ po tyrimo $(\mathrm{p}<0,05), 2$-osios gylis pakito nuo $6,46 \pm 0,3 \mathrm{~mm}$ iki 6,27 $\pm 0,3$ $\mathrm{mm}(\mathrm{p}<0,05), 3$-iosios - nuo 6,16 $\pm 0,6 \mathrm{~mm}$ sumažèjo iki $6,03 \pm 0,4 \mathrm{~mm}(\mathrm{p}<0,05)$. Po dviejų savaičių raukšlių gylis išliko patikimai sumažèjęs $(p<0,05)$ lyginant su verte, buvusia prieš prasidedant tyrimui. Smulkiosios raukšlès dèl savo tolygesnio reljefo greičiau reaguoja ị drègmès lygio odoje pokyčius ir labiau pasisavina kosmetinių priemonių aktyviąsias medžiagas, todèl galima buvo užfiksuoti jų gylio teigiamą, nors nereikšmingą pokytị. Kosmetinès kaukès sudètyje esantis biopeptidas acetilheksapeptidas 8 mažina raumenų inervaciją, neleisdamas dar labiau gilèti raukšlèms bei acetilheksapeptidas 12, skatinantis fibroblastus aktyviau gaminti kolageną, todèl gereja veido odos atsistatymas, taip pat mažèja raukšlès. I jauninančios kaukès sudètị ịeinantis galingas antioksidantas hidroksidecil ubichinonas (CoQ10) apsaugo ląsteles nuo žalingos aplinkos, lygina smulkias raukšleles, dehidrataciją ir išlygina odos tekstūrą.

İvertinus subjektyvius veido odos būklès vizualinių (4 pav.) bei jutiminių rodiklių pokyčius (5,6 pav.), galime teigti, kad jauninamoji kaukè pagerino vertintus rodiklius. Didèjant drègmei, tiriamosios ịvardijo, kad skaistumas didèjo, o šerpetojimas mažejo $(p<0,05)$. Po tyrimo veido skaistumą pastebimai mate 42 proc tiriamujų, veido odos šerpetojimas nevargino 72 proc. moterų.

Drègmès ir jutiminių rodiklių - tempimo jausmo ir švelnumo - sąveika taip pat teigiama. Didèjant drègmei, veido odos tempimo jausmas mažèjo - tempimo jausmo nejauté 80 proc. moterų, odos švelnumas didejo - pasibaigus tyrimui, švelnumą pastebimai jautè daugiau nei pusè tiriamujų $(\mathrm{p}<0,05)$.

Jauninamoji kaukè padidino veido odos elastingumą $(\mathrm{p}<0,05)$, o kartu tyrime dalyvavusios moterys pajaute, kad jų odos stangrumas taip pat didejja $(\mathrm{p}<0,05)$. Tyrimui pasibaigus, 73 proc. tiriamujų teigè, kad jų odos stangrumas stipriai jaučiamas. Odos stangrumo didejjimui įtakos turèjo padidèjęs drègmès kiekis, elastingumo lygis bei suaktyvejjusi kolageno gamyba dèl biopeptido algilerino (acetilheksapeptido 8).

\section{Išvados}

1. Veido odos drégmė kaktos bei skruostų srityse ir odos elastingumas reikšmingai padidejo po 8 savaites taikytų jauninamujų kaukès procedūrų. Šio tipo kaukè taip pat turèjo teigiamą, statistiškai reikšmingą poveikį trijų raukšlių, matuotų ties išoriniu akiduobès kampu, gyliui.

2. Jauninamoji kaukè padare teigiamą įtaką subjektyviems veido odos rodikliams. Vizualiniai - skaistumas ir šerpetojimas, bei jutiminiai - tempimas, švelnumas, stangrumas - rodikliai reikšmingai pagerejjo po taikyto 8 savaičių kurso.

\section{Literatūra}

1. Sparavigna A, Di Pietro A, Setaro M. Healthy skin: significance and results of an Italian study on healthy population with particular regard to sensitive skin. International Journal of Cosmetic Science 2005; 27(2), 327-331.

https://doi.org/10.1111/j.1467-2494.2005.00287.x

2. Saxon SV, Perkins EA, Etten MJ. Physical Change and Aging, Sixth Edition: A Guide for the Helping Professions. New York, NY: Springer Publishing Company, 2015.

3. Wong R, Geyer S, Weninger W, Guimberteau J, Wong J K. The dynamic anatomy and patterning of skin. Experimental Dermatology, 2016; 25(2), 92-98. doi:10.1111/exd.12832. https://doi.org/10.1111/exd.12832

4. Imada M, Ekiguchi A. Skin Aging: New Research. Hauppauge, N.Y.: Nova Science Publishers, Inc., 2013.

5. Gaur M, Dobke M, Lunyak V V. Mesenchymal stem cells from adipose tissue in clinical applications for dermatological indications and skin aging. International Journal of Molecular Science 2017; 18(1): 208.

https://doi.org/10.3390/ijms18010208

6. McLafferty E. The integumentary system: anatomy, physiology and function of skin. Nursing Standard (Royal College Of Nursing (Great Britain):1987). 2012; 27(3), 35-42.

7. Mahrhauser D, Nagelreiter C, Baierl A, Skipiol J, Valenta C. Influence of a multiple emulsion, liposomes and a microemulsion gel on sebum, skin hydration and TEWL. International Journal of Cosmet Science 2015; 37(2):181-62015.8.

8. Brincat MP, Baron YM, Galea R. Estrogens and the skin. Climacteric, 2005; 8(2):110-23.

9. Calleja-Agius J, Brincat M. The effect of menopause on the skin and other connective tissues. Gynecological Endocrinology 2012; 28(4), 273-277. https://doi.org/10.3109/09513590.2011.613970

10. Augustyniak A M, Rotsztejn H, Bartnicka E, Budzisz E. Effects of reactive oxygen species on skin photoaging. Dermatology Review / Przeglad Dermatologiczny 2016; 103(3): 233-239. https://doi.org/10.5114/dr.2016.60630 
THE EFFECT OF ANTI-AGING COSMETIC MASK ON AGING SKIN

B. Kaušilaitė, A. Juškevičienė, V. Vaikšnorienė, Ž. Mickienė, L. Valatkevičienè, A. Klimavičienė, S. Čapkauskienė

Key words: cosmetic mask, aging, moisture, elasticity, wrinkles.

Summary

With aging, the facial wrinkles that are already formed are deepening, the face oval slips down, the cheeks are removed, the eyebrows spread, the eyeballs grow, and the normal blood circulation of the face of the skin is disturbed. Changes in hormonal balance, and in the postmenopausal period, decreased estrogen levels cause collagen degradation, loss of water, loss of elasticity. Due to high employment rates and unequal financial possibilities, part of women's day care is limited to skin cleansing and lubrication. To achieve better results, additional cosmetic products are needed: scrubs, masks, and serums. The aim of the study was to evaluate the effect of modern cosmetic masks designed for use at home on the development of aging facial skin. Methods: 1. assessment of condition of the condition by diagnostic apparatus "Skin analyzer Soft plus". 2. anti-aging mask procedures: 16 procedures were performed, 2 times/week. Twenty-four women aged 35-50 years participated in this study. Results: the moisture content of the forehead increased from $58.9 \pm 10.2$ (relative units) up to $65.5 \pm 10$ (relative unt.) at the end of the study $(\mathrm{p}<0.05)$, the moisture in the cheeks zone increase from $62.5 \pm 10$ (relative unt.) up to $69 \pm 10.5$ (relative unt) $(\mathrm{p}<0.05)$. The face elasticity also increased from 40 \pm 3.3 (relative unt.) at the beginning of the study to $47.5 \pm 3.9$ (relative unt) at the end of study $(p<0.05)$. The depth of wrinkles increased reliably and remained less after 2 weeks compared to their initial value $(p<0.05)$. Sensual and visual facial skin indexes have improved $(\mathrm{p}<0.05)$. Conslusions: facial skin moisture in the forehead and cheek areas and skin elasticity increased significantly after 8 weeks of anti-aging mask treatments. Also, this type of mask has had a positive, significant effect on the depth of the three folds measured at the outer corner of the eye. An anti-aging mask has had a positive effect on the assessment of subjective facial skin characteristics. Visual - beauty and brushing, and sensory - stretching, tenderness and stiffness - indicators have significantly improved.

Correspondence to: sandrija.capkauskiene@go.kauko.lt

Gauta 2017-11-02 